\title{
THE INDIVIDUALIZATION OF EDUCATION IN SECONDARY SCHOOL OF UKRAINE AND PEDAGOGICAL PSYCHOLOGY (THE SECOND HALF OF THE $20^{\mathrm{TH}}$ CENTURY)
}

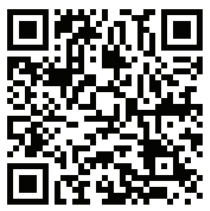

To cite this article:

\author{
Natalia Dichek, Dr. Sc., Prof. \\ Head, Department of History and Philosophy of Education, \\ Institute of Pedagogy, \\ National Academy of Educational Sciences of Ukraine \\ Kyiv, Ukraine \\ ip.istp@gmail.com \\ https://orcid.org/0000-0002-2185-3630
}

\begin{abstract}
In the context of the introduction in the second half of the $20^{\text {th }}$ century the process of the individualization of teaching in secondary school a little-studied aspect is revealed - the contribution to this process of Ukrainian psychologists. The main directions of their research, methods and results of scientific experiments in the field of pedagogical psychology, psychology of personality, social psychology aimed to individualizing education (studying memory, individual differences in mental activity, creativity of students, their interests and abilities, identifying and developing giftedness and creative thinking, introducing the differentiation in education in primary school, the organization of psychological service in secondary school) are outlined. The analysis of such kind of Ukrainian scientists' studies testified the expansion in the early 1990s of the spectrum of their work in the direction of ensuring the realization of individual needs and interests of schoolchildren. It was proved the gradual formation during the 1980s of a basis for establishing the paradigm of a personality-oriented education, which became one of the most important directions of the educational policy of independent Ukraine.
\end{abstract}

Key words: differentiation and individualization of schooling; personal approach; the paradigm of personality-oriented education; psychological service in school.

\section{INTRODUCTION. PROBLEM STATEMENT}

To investigate the historical retrospective of the problem of the individualization and differentiation of education in secondary school in Ukraine, it is necessary to disclose the achievements of Ukrainian scholars in the field of pedagogical psychology, which contributed significantly to the implementation of the individual approach to students. Our numerous previous publications (Dichek, 2013-2016) show the results of the work of scientists in the mentioned industry, acquired from the late nineteenth century until the 80 's of the twentieth century. This article is a generalization and a logical continuation (including the 1990s) of existing studies. 


\section{LITERATURE REVIEW}

The relevance of studying this issue is motivated by the current significance of further development and deepening of the personality-oriented approach to school students based on the individualization and differentiation of the educational process. Yu. Hilbukh (1991), A. Furman (1993), I. Beh, S. Lohachevska, V. Rybalka (1998), H. Ball, S. Podmazin, P. Sikorskyi, A. Samodrin (2000), H. Kobernyk (2002), I. Dychkivska (2004), T. Wozhehova (2008), O. Savchenko (2012), S. Maksymenko (2013) added to elaboration of child-centered principles of work of a modern Ukrainian school. At the same time, it is important to find out the scientific research knowledge accumulated in the past, which became largely not only the basis of modern studies on the personality of a student in conjunction with the psycho-physiological and social factors of its development on the background of educational activity, but also contributed to the development and humanization of teaching practice in accordance with the received theoretical and practical results in psychology.

\section{METODOLOGY}

The purpose of the article is to highlight the main directions of psychological and pedagogical research in the field of the individualization of schooling through the analysis of the achievements of Ukrainian researchers in the field of pedagogical psychology, carried out during the second half of the 20-th century. It should be noted that the objects from the sphere of general psychology are partially included, in particular, personal psychology, as well as social psychology, which directly or indirectly related to the aspects of the individualization of the educational process. The methodological basis of the study was an analysis of published texts, a comparison of their content, a hermeneutical approach to their interpretation, combined to make possible conclusions.

\section{MAIN RESULTS}

Before revealing the achievements of Ukrainian researchers, we remind that in the 1960s (after the International Psychological Congress, held in 1966 in Moscow), the return of Soviet psychology to the world professional community took place after a long scientific isolation (Petrovskij, A., Jaroshevskij M., 1996: p. 279-280). A certain release of scientific thought has also positively influenced the further development of Ukrainian psychological science. Nevertheless, according to historians (ibid.: p. 273), partocratic pressure on the psychological community of the country has not weakened.

It should also be taken into account that in the late 1950s, under the influence of the adopted Law "On strengthening the connection of school with life and further development of the system of public education" (1958), the problem of the differentiation of approaches to education became relevant. As a result, the thematic field of psychological and pedagogical studies in Ukraine, along with studying students' individual mental functions (perception, thinking, speech, memory, and self-regulation), aspects of the process of teaching students again included the problems of studying the abilities and psychology of personality.

As a famous Ukrainian scientist H. Kostiuk, director of the Research Institute of Psychology of the Ukr.SSR (hereinafter - Research Institute of Psychology) noted in 1958, 
at that time, in Soviet psychology, there was no experimentally confirmed theoretical basis for the diagnosis of giftedness and the determination of abilities (TsDAVO Ukrainy, 1958: p. 3-4), so the diagnostics of gifted students caused difficulties. He warned against the introduction of complete differentiation in teaching in upper forms of secondary school also because of "the impossibility of opening schools with differentiated education in small towns, villages, uncertainty in planning of the number of classes of a particular subject profile" (ibid.: p. 6). At the same time, the scientist stressed the importance of deepening the "individual approach to existing organizational forms of education", which should extend not only to backward students but also to gifted ones (ibid.: p. 7).

The long-term study of the peculiarities of memory development, in particular the study of the problem of involuntary memorization (1961) by the Ukrainian psychologist P. Zinchenko with his colleagues and students (Kharkiv Pedagogical Institute), contributed to the development of scientific ideas about the specifics and individual differences in the acquisition of knowledge by children. To the most important for school practice conclusions of P. Zinchenko, which allowed to conduct students' memory in the process of learning, is the statement that "the main line of development of child's memory - is the path of changing involuntary processes of memory into arbitrary, that $\langle\ldots\rangle$ does not mean stopping the development of involuntary memory. $<\ldots>$ development of memory - is actually enriching with knowledge" (Zinchenko, 1970: p. 30). It should be noted that under the notion of "enrichment" it is meant not just the accumulation of knowledge, but the formation of a system of knowledge and "ways of organizing the stored information", which sounds like an important scientific foresight and is still an actual task.

The analysis of subjects of psychological and pedagogical works proves that Ukrainian researchers paid considerable attention to studying the peculiarities of the acquisition of knowledge by primary school pupils. Thus, during the forming experiment in two schools in Kyiv (1964-1965 school year), a scientist of the Institute of Psychology O. Skrypchenko (later - a well-known scientist, professor) studied the change in the dynamics of mental development of pupils of the 1st-2nd forms, depending on the content and methods of teaching, which he rebuilt on author's principles in the direction of "revealing the logical structure of educational material, the detection of basic concepts, increasing the theoretical level of education, accelerating in children the formation of generalizations, as well as the motives necessary for educational activity" (Skrypchenko, 1967: p. 4). His research showed that studying in experimental conditions facilitated a marked acceleration of students' mental development. The changes also occurred in the individual differences of this development, and they did not diminish, but with the increasing complexity of mental operations gradually broadened (ibid.: p. 9).

According to the results of the experimental study (1967) of the individual psychological aspects of teaching first-formers reading, B. Bohuslavska from the Izmail Pedagogical Institute came to a significant conclusion: speed, perception and comprehension of a text are determined by the speed and flexibility of the relationships that are formed in children between the visual and acoustic stimuli from one hand, and linguistic-motor reactions from the other (Bohuslavska, 1967: p. 36). Such features predetermined the existence of four different types of reading among students, depending on speed, accuracy and comprehension of a text. This made it possible to outline the possible ways of working with each group of students. We consider her approach as an example of the introduction of internal (within the classroom) differentiation of education. 
Return to studying a student's personality motivated scientists' more frequent addressing to the determination of a scope of his interests. Thus, in 1967, a scientist from the Research Institute of Psychology, O. Kyrychuk (later - an academician of the National Academy of Educational Sciences of Ukraine), unveiled the results of investigation of a problem connected with formation of interest in primary school students as a means of their successful education and individualization. Having surveyed 2340 schoolchildren of urban and rural schools in Kyiv, Kyiv and Transcarpathian regions, he established a specific weight of educational interests in the structure of children's activities of a particular classroom. He substantiated that one of the most important factors determining the level of educational interest of a certain student group is the personality of a teacher, his ability to cause in a child positive emotions and the joy of success, create the appropriate speed of acquisition of knowledge. As a result, O. Kyrychuk stated: "Qualitative analysis of teachers' work in classes with a high degree of interest in educational activity shows that it is very important to create optimal conditions for certain groups of students with different studying potential, that is provide to a broad individual approach, the differentiation of education" (Kyrychuk, 1967: p. 67).

Significant social-psychological studies, indirectly linked with the intensification of the individualization of the educational process in secondary school, include the theoretical and experimental study of "subjective-objective relations" (Voitko, 1982: p. 13) in educational groups was conducted by professor V. Voitko (with colleges from the Institute of Psychology). Since the mid-1970s, they developed a rather innovative for the Soviet psychology role-personality principle of organizing the educational process in school (ibid.: p. 3). This principle in essence and according to the author's intention was a modification of the principle of the individualization. According to this approach the significance and worth of a personality were clearly highlighted in the conditions of priority of collective principles in the life of society of that time.

At the same time, there was a significant gap between the achievements of scientists and the introduction of the results of their research into the educational process. There was an increased need for "psychologizing" of school practice. Although Ukrainian scholars in the 1970s continued to study the mainly partial questions of psychology of education, acquisition of knowledge by students, their strength (Za kruhlym stolom, 1975), which can be characterized as a functionalism of researches, even then the basis for development of the subjective approach to education in future, spreading of ideas of developmental education, cooperative education began gradually to form. A vivid proof of this is the psychological and pedagogical heritage of V. Sukhomlynsky, who in the 1960s theoretically established and actually implemented, although in a separate rural Pavlysh school, a personalityoriented approach to the education of schoolchildren.

In the 1980s professor S. Maksymenko (nowadays - an academician of the National Academy of Educational Sciences of Ukraine) with a group of co-workers of the Laboratory of Psychology of Education of the Research Institute of Psychology on the basis of the experiment on the formation of generalized methods for solving practical problems among students of secondary schools in Kyiv (Nos. 21, 180, 183, 201) developed the methodological aspects of the individualization of the educational process (Maksymenko, 1988: p. 6). An important contribution to the psychology of education was the work of H. Ball "Theory of educational tasks" (1990), which disclosed a "task-oriented approach" to organizing a schooling on the base of using qualitative and 
quantitative characteristics of tasks for assessing academic achievements and intellectual development of students.

It should be noted that for psychological and pedagogical researches of the early 1980s the activation of the development of issues of professional self-determination of students in the process of vocational education was also characterized as an option to ensure the unlock of individual dispositions and opportunities of schoolchildren, and hence the promotion of their life self-realization. Since the mid-1980s, the methodological, theoretical and applied aspects of the formation of an all-round and harmoniously developed personality, which corresponded to the leading "historical decision of party congresses" in the field of education of that time, became the priority issues in the researches of Ukrainian psychologists. Although the instructions of the authorities were still important in determining the directions of scientific researches of the educational process, the analysis of the subjects and content of psychological and pedagogical studies convinced that they also reflect the developed in the depths of science intention of formation of not an average, impersonal, ideal "harmonic personality", but of implementation of personal-oriented tasks for development of children's creativity in the process of education, overcoming formalism in the goals and approaches to complex processes of personality creation, in particular in the dimension of interpersonal relationships between students, ensuring the realization of their individual needs and motives of education.

Taking into account the obtained theoretical and experimental conclusions and the results of the effective experience of innovative teachers in the 1980s, attempts were made to rethink the problems of psychology of teaching in accordance with the needs of a changing social situation, to review the mechanism of interpersonal interaction between a teacher and a student, and to take into account the factor of students' influence on each other (Maksymenko, 1988: p. 6). It should be noted that for the first time in 1989, on the pages of the collection of works "Psychology" scientists H. Ball and L. Taranov substantiated the need for the personal approach in defining the goals of education (Ball \& Taranov, 1989: p. 8).

When in 1991 Ukraine finally gained its independence and chose an evolutionary way of state building, it became necessary to reform the existing authorities, sociocultural institutions, which include education, and organization of new ones that would meet the needs of a sovereign state (Ukraine in ...). As the beginning of the state-building process in Ukraine was accompanied by objective socio-economic difficulties, society as a whole and the educational sector in particular were in a crisis, there was a discrepancy between education and personal needs, social needs and world achievements of mankind (Low of Ukraine...,1991). At the same time, pedagogical crisis phenomena such as "the estrangement of schoolchildren from teacher, from school, and, consequently, from society as a whole" (Hilbukh, 1993: p. 3), were also accumulated in education during the previous years. The reasons for estrangement, which were ascertained in the course of studying the state of school education, in many respects were related to poor teachers' knowledge of the psychological individuality of their students and lack of proficiency in using methods to get to know it, for the correction of development or ensuring accelerated personal development of schoolchildren (ibid.: p. 4).

The release in the early 1990s of the Ukrainian socio-humanitarian thought and educational practice from the hard tent of monoideological imperatives promoted spreading of ideas about the need for humanization of the entire educational sphere. 
Thus, the Law on Education (1991, substantial editing - 1996) among the basic principles of education (asset 6) declared "humanism, democracy, the priority of universal human spiritual values; organic connection with the world and national history, culture, traditions" (Low of Ukraine...).

However, in fact, the first document developed in sovereign Ukraine on the strategic paths and priority directions of reforming the educational sector was the State National Program "Education" ("Ukraine 21-st Century") approved in November 1993 by the Cabinet of Ministers of Ukraine. Its project was approved at the 1st Congress of Teachers of Ukraine (1992). The Program referred to the need to reproduce the intellectual, spiritual potential of the people, the emergence of domestic science, technology and culture at the world level, the national revival and democratization of the society in Ukraine (Derzhavna natsionalna prohrama ..., 1993). The proclamation was also made of the necessity of creating "psychological and social-pedagogical services in educational institutions". They were seen as one of the main ways of reforming secondary education.

As the most complete satisfaction of personal needs was recognized person to be the educational priority of state policy in Ukraine, we think a final turn to humancentered education was made. It should be also borne in mind that it was chiefly prepared, according to our research, in the second half of the 1980s. Therefore, in the early years of independence, scientists were able to immediately begin updating the theoretical and practical approaches to studying the development of a growing person, which activated in Ukraine such a field as practical psychology, that is closely connected with "the individualization and differentiation and the necessity of taking into account the level of physical and spiritual development of a student" (Kyrychuk, 1993: p. 7). The culture of using of psychological knowledge by teachers has become recognized as "an integral part of humanization of the educational process" (Tyshchenko,1993: p. 59).

At the same time, as claimed in 1992 by a psychologist V. Panok, an active participant in the organization of the pedagogical service in Ukraine (now - the head of the Ukrainian Scientific and Methodical Center of Practical Psychology and Social Work), the reason for the growth of the request for practical psychology was not only the "introduction of humanistic principles in the relationship between the state and the individual" (Panok, 1993: p. 14), but also the awareness of the need for the application of psychological knowledge in the educational process, which began "from the bottom", in schools, from including the position of a psychologist in their staff. Recalling that since the differentiation of education, providing development of abilities and talents of children was recognized as the key objectives of school education, the scientist emphasized: without psychologists and psychology, their implementation is impossible, as well as solving problems of vocational guidance and vocational selection, behavioral problems, creating qualitatively new textbooks, predicting trajectories of mental development of children (ibid.: p. 17).

According to our opinion, the psychologization of school practice has become one of the key ways of its humanization during the period of statehood development. The intensive use of the achievements and opportunities of practical psychology, implementation of methodical tools for psychodiagnostics in school began, the organizational structure for the functioning of which the psychological service of school (PSS) was installed. Its legitimization in Ukraine took place with the adoption in 1993 
of the Regulations on the psychological service in the educational system (Regulations on the psychological ..., 1993). Subsequently, it has been repeatedly edited owing to changes in legislation and practical needs.

It was obvious that one school psychologist was unlikely to be able to provide a full range of jobs specified in the regulations. This was already known at the beginning of deployment of the school psychological service in the country from the works of a well-known psychologist Yu. Hilbukh, one of the founders of implementation of psychodiagnostics in Ukrainian schools (Vereshchak, 2013). The scientist made a significant contribution to the return to the scientific and practical circulation of psychodiagnostics as an effective tool for studying the nature of a child. It was precisely in his (since 1989) Laboratory of Psychodiagnostics and Psychology of Differentiated Education of the Research Institute of Psychology that the necessity of introducing the positions of school psychologists in Ukraine, which was reflected in the State National Program "Education: (Ukraine 21-st Century)" (Derzhavna natsionalna prohrama ..., 1993) was substantiated (Institute of psychology ...). In the scientific department they were engaged in the development of special programs and educational complexes, which teachers and school psychologists could use when working with different categories of children, that is, to implement a differentiated approach. And it was Yu. Hilbukh who became the first Ukrainian psychologist who experimented with his colleagues on the introduction of a system of three types of classes in elementary school system, which provided differentiated staffing of primary classes in secondary school through the distribution of children by their level of readiness for studying based on the use of a set of portable test methods, developed in the Laboratory of Differentiated Learning (Hilbukh, 1991).

However, according to L. Kondratenko, a colleague of a scientist and an active participant in the experimental work of the Laboratory, during the 1990s owing to a number of reasons - external (rapid, largely unbalanced socio-economic changes in the life of society) and internal (imperfection, flaws in the practical implementation of classroom differentiation in schools, lack of financing) - in fact, in the country "there was a ramified system of differentiated education, oriented mainly not to meet the needs of each child through the individual approach, but to select more gifted (and sometimes - more affluent) children. $<\ldots>$ the "wild" capitalism was accompanied by the "wild" differentiation" (Kondratenko, 2017: p. 255). Under the pressure of circumstances, the experimental studying the possibilities of class differentiated education, in particular for the propaedeutics of school failure, gradually lost its attractiveness for teachers and "with the beginning of the new century it almost disappeared officially from the work of secondary schools, although it remained in certain hidden forms" (ibid.: p. 256).

The reasons for the decline of this direction of the individualization of school education should include the professional unpreparedness of teachers to the implementation of class differentiation in schools, their ignorance with its psychological principles and tasks. This situation motivated the Ukrainian scientists (I. Bohdanova, O. Skrypchenko, A. Markova, N. Chepelieva) to raise the issue of the need to strengthen a psychological component of training of future teachers and retraining persons already working in the educational field. 


\section{CONCLUSIONS}

During the second half of the 20-th century, Ukrainian psychologists took an active part in the gradual directing teaching of schoolchildren in the course of its individualization and differentiation, which contributed to the development of the ideas about humanization of education. They prepared theoretically and experimentally grounded basis for the transition of education in Ukraine from the paradigm of the "school of learning" to the child-centered personality-oriented paradigm. We believe that the most significant vector in the process of humanizing the school in the country in the first decade of its independence was multidimensional psychologization of the educational branch. A real embodiment of psychologization was the creation of psychological service in school, increasing attention to practical psychological and pedagogical training of future teachers and retraining of working educators. The achievement in using the potential of practical psychology, acceptance of its relevance and utility was the organization in 1998 of Ukrainian Scientific and Methodological Center for Practical Psychology and Social Work as a scientific institution in the system of the Academy of Educational Sciences of Ukraine (since 2010 - the National Academy of Educational Sciences of Ukraine).

The study of the processes related to the individualization of the education in secondary school of Ukraine convinced that at the beginning of the $21^{\text {st }}$ century, the state's attention to the issues of psychologization of the educational process, both in school and in the preparation of psychological and pedagogical staff, was intensified. At the same time, such an increase in the awareness of psychological and pedagogical support for the development of personality is explained largely by the activity of scientific and educational communities and their influence on the adoption of crucial decisions in the educational sphere by the authorities. However, it should also be admitted that there were socio-economic difficulties in independent Ukraine, which prevented the rapid achievement of the desired results in terms of qualitative spreading of psychological knowledge, besides such a process could not be quick from an objective scientific point of view.

\section{REFERENCES}

Ball, G. \& Taranov, L. (1989). Osobystisnyi pidkhid do vyznachennia tsilei vykhovannia ta shliakhiv yikh dosiahnennia [Person oriented approach to determine the aim of education and the ways of its achieving]. Psykholohiia: Resp. naukovo-metodychnyi zbirnyk, 32, 7-15.

Ball, G. (1990). Teoriya uchebnykh zadach. Psikhologo-pedagogichnyy aspekt [Theory of educational tasks. Psychological and pedagogical aspects]. Moskva: Pedahohyka. (in Russian)

Bohuslavska, B. (1967). Psykholohichni osnovy indyvidualizatsii navchannia chytannia [The Psychological basics of teaching students to read]. Psykholohiia: Resp. naukovometodychnyi zbirnyk, 4, 31-38.

Derzhavna natsionalna prohrama "Osvita" (1993): Ukraina XXI st. [State national program "Osvita” (1993). Ukraine 21-st century]. Osvita, 44-46; 1-13.

Dichek, N. (2013). Psykholoho-pedahohichni doslidzhennia v URSR u konteksti indyvidualizatsii shkilnoho navchalnoho protsesu (1945 - pochatok 1950-kh rokiv) [Psychological and pedagogical research in the Ukrainian SSR in the context of the individualization of the school educational process (1945 - early 1950s)]. Ridna shkola, 11, 29-37.

Dichek, N. (2013). Vnesok vitchyznianoi eksperymentalnoi pedahohiky v obgruntuvannia 
neobkhidnosti indyvidualizatsii ta dyferentsiatsii navchalno-vykhovnoho protsesu (kinets XIX - 1917 r.) [Contribution of domestic experimental pedagogy to substantiate the necessity of individualization and differentiation of the educational process (end of $19^{\text {th }}$ 1917)]. Dyferentsiiovanyi pidkhid $v$ istorii ukrainskoi shkoly (kinets XIX - persha tretyna XIX st.): kolektyvna monohrafiia [In collective monograph: Differentiated Approach in the History of the Ukrainian School (end of the $19^{\text {th }}$ - first third of the $20^{\text {th }}$ cen.) ]. Kyiv: Ped. Dumka, 32-73.

Dichek, N. (2014). Doslidzhennia ukrainskykh psykholohiv u haluzi indyvidualizatsii shkilnoho navchalno-vykhovnoho protsesu (60-70-ti rr. XX st.) [Researches of the Ukrainian psychologists in the field of an individualization of schooling (the $60-70^{\text {th }}$ of $20^{\text {th }}$ cen.) ]. Pedahohika i psykholohiia, 4, 76-83.

Dichek, N. (2015). Formuvannia osobystisno oriientovanoi paradyhmy shkilnoi osvity u doslidzhenniakh ukrainskykh psykholohiv (1980-ti rr.) [Cultivating of personal oriented paradigm of schooling in Ukrainian psychologists' researchers (the1980 $\left.{ }^{\text {th }}\right)$ ]. Pedahohika i psykholohiia, 4, 15-29.

Dichek, N. (2015). Vnesok ukrainskykh psykholohiv u rozvytok dyferentsiatsii navchannia shkoliariv (60-ti rr. XX st.) [Contribution of the Ukrainian psychologists in progress of differentiation of students schooling (the $60^{\text {th }}$ of $20^{\text {th }}$ cen.) ]. Pedahohichna osvita: teoriia i praktyka: zbirnyk naukovykh prats, 18 (1-2015), 407-419.

Dichek, Natalia. (2016). Ways to establish the personal oriented paradigm in the Ukrainian school education (Psychological and pedagogical aspects). The Modern Higher Education Review (International Journal), 1, 74-83.

Hilbukh, Yu. (1991). Psykholohichni peredumovy dyferentsiiovanoho navchannia u pochatkovii shkoli [Psychological premises of differentiation in primary teaching]. Psykholohiia: Resp. naukovo-metodychnyi zbirnyk, 36, 62-71.

Hilbukh, Yu. (1993). Uchitel i psikhologicheskaya sluzhba shkoly [The teacher and the psychological service in school]. Kiev. (in Russian)

Instytut psykholohii imeni H.S.Kostiuka [Institute of psychology (H. Kostyuk Institute of psychology)]. Retrieved from http://inpsy.naps.gov.ua/info/185

Kondratenko, L. (2017). Psykholohiia pervynnoi shkilnoi neuspishnosti: monohrafiia [Psychology of primary school failure: monograph]. Chernihiv: Desna Polihraf. (in Ukrainian)

Kyrychuk, O. (1967). Vyvchennia navchalnykh interesiv u ditei molodshoho shkilnoho viku [Studying of educational interests in children of primary school age]. Radianska shkola, $3,1-7$.

Kyrychuk, O. (1993). Stan i perspektyvy rozvytku praktychnoi psykholohii v systemi narodnoi osvity v Ukraini [The state and prospects of the development of practical psychology in the system of public education]. Psykholohiia: naukovo-metodychnyi zbirnyk, 40, 3-15.

Law of Ukraine on Education. Retrieved from http://zakon3.rada.gov.ua/iaws/show/1060-12 Maksymenko, S. (1988). Metodolohichni aspekty psykholohii navchannia [Methodological aspects of the psychology of schooling]. Psykholohiia: Resp. naukovo-metodychnyi zbirnyk, 31, 3-11.

Panok, V. (1993). Sytuatsiia i perspektyvy rozvytku praktychnoi psykholohii v Ukraini [State and prospects of the development of practical psychology in Ukraine]. Psykholohichni problemy vykhovannia, navchannia, aktyvnosti ta rozvytku osobystosti: materialy zvitnoi naukovoi sesii Instytutu psykholohii APN Ukrainy, 22-24.02 1993r., II, 14-21.

Petrovskij, A. \& Jaroshevskij, M. (1996). Istoriya i teoriya psikhologii [History and theory of Psychology]. Rostov-na-Donu: "Feniks". (in Russian) 
Regulations on the psychological service in the educational system of Ukraine (1993). Retrieved from http://zakon3.rada.gov.ua/laws/show/z101-93

Skrypchenko, O. (1967). Zmina dynamiky rozumovoho rozvytku uchniv 1-2-kh klasiv zalezhno vid zmistu i metodiv navchannia [Changes in the dynamics of mental development of the 1st - 2nd grades pupils' depending on the content and methods of teaching]. Psykholohiia: Resp. naukovo-metodychnyi zbirnyk, 4, 3-10.

TsDAVO Ukrainy. NYY psykholohyy ynstytuta psykholohyy USSR Mynysterstva prosveshchenyia USSR. Stenohrama zasidannia vchenykh Rad Instytutu pedahohiky ta Instytutu psykholohii" (vid 11 hrudnia 1958 r.) [Central State Archive of the Supreme Authorities of Ukraine (tsdavo@arch.gov.ua.), Documents of Scientific research Institute of Psychology of Ukr. SSR. Shorthand record of the meeting of scientific councils of the Institute of Pedagogy and Institute of Psychology of Ukr. SSR (11.12.1958)], F.5141, op.1, spr.129, 43 ark.

Tyshchenko, S. (1993). Osoblyvosti vykorystannia psykholohichnykh znan uchyteliamy pry kharakterystytsi nymy osobystosti shkoliara ta rozviazuvanni problemnykh pedahohichnykh sytuatsii [The peculiarities of the use of psychological knowledge by teachers in characterizing a schoolchild's personality and solving problem pedagogical situations]. Psykholohichni problemy vykhovannia, navchannia, aktyvnosti ta rozvytku osobystosti: materialy zvitnoi naukovi sesii Instytutu psykholohii APN Ukrainy, 22-24.02.1993 r., II, 59-66.

Ukraina $\mathrm{v}$ umovakh nezalezhnosti [Ukraine in the circumstances of independence]. Retrieved from http://mestectvo.com/istoriya-ukraini/independence.html

Vereshchak, Ye. (2013). Kerivnyk i yoho komanda: do 85-littia vid dnia narodzhennia Yu.Z.Hilbukha [Manager and his command: to the 85th anniversary of Yu.Hilbukh birth]. Praktychna psykholohiia i sotsialna robota, 7, 72-75.

Voitko, V. (1982). Nasushchni problemy rozvytku psykholohii v odynadtsiatii piatyrichtsi [Modern problems in the development of Psychology in the 11th piatyrichka]. Psykholohiia: Resp. naukovo-metodychnyi zbirnyk, 2, 3-15.

"Za kruhlym stolom" (1975): obhovorennia na temu "Psykholohichni aspekty navchannia, vykhovannia i osvity u rozvynutomu sotsialistychnomu suspilstvi" (vidbulosia na zasidanni rozshyrenoi redkolehii zbirnyka "Psykholohiia", 11 lystopada 1974 r.) ["Round table". (1975): discussion on "Psychological aspects of teaching and education in the developing socialistic society" (conference of scientists and editor staff of scientific collection a "Psychology", 11.11.1974)]. Psykholohiia: Resp. naukovo-metodychnyi zbirnyk, 14, 3-34.

Zinchenko, P. \& Sereda, H. (1970). Rozvytok pamiati uchniv u protsesi navchannia [Developing the memory of students in the schooling process]. Psykholohiia: Resp. naukovometodychnyi zbirnyk, 8, 18-31. 